*УДК 336:004.896(07)

Пиріг С.О., к.е.н., доцент

Вахновська Н.А., к.е.н., доцент

Іщук Л.І., к.е.н., доцент

Луцький національний технічний університет

\title{
РОЛЬ ПЛАТІЖНИХ СИСТЕМ В РОЗВИТКУ БЕЗГОТІВКОВОЇ ЕКОНОМІКИ УКРАЇНИ
}

У статті зроблено аналіз грошових переказів за допомогою платіжних систем та досліджено їх роль у розвитку безготівкової економіки.

Ключові слова: платіжні системи, грошові перекази, безготівкові розрахунки, платіжні картки, переказ з картки на картку.

Pyrih S., Vahnovska N., Ischuk L.

\section{THE ROLE OF PAYMENT SYSTEMS IN DEVELOPMENT CASHLESS ECONOMY OF UKRAINE}

The development of the «cashless economy» is one of the priorities of financial regulators in a number of countries, both developed and developing countries. A significant number of companies and business associations are working on the creation and development of the necessary tools and mechanisms for this. In Ukraine, the rate of development in this area is still insufficient, where a number of barriers slow down the crowding out of cash. On the one hand, the strategic motion on the development of the cashless economy, at the level of state bodies and at the level of the largest players in the financial market, has been repeatedly declared, and, on the other hand, the growth rate of cashless circulation is insufficient and certain efforts should be made to accelerate it.

The payment system is an integral part of virtually all economic transactions relating to the transfer of monetary value in exchange for goods, services or financial assets in a non-cash form. The form of organization of cashless payment transactions is a payment system. Payment systems play an important role in ensuring economic activity: create conditions for the movement of funds between economic operators, enable the effective use of financial resources, and conduct state monetary policy. The organization of payment systems of the state directly influences the stability of its financial system, the level of expenses of money circulation, the cost of economic operations, the liquidity of financial markets and the banking system, that is, the efficiency of the functioning of the economy as a whole.

Key words: payment systems, money transfers, non-cash payments, payment cards, transfer from card to card.

* Пиріг С. О., Вахновська Н. А., Іщук Л. І. 
Пыриг С.А., Вахновская Н.А., Ищук Л.И. РОЛЬ ПЛАТЕЖНЫХ СИСТЕМ В РАЗВИТИИ БЕЗНАЛИЧНОЙ ЭКОНОМИКИ УКРАИНЫ

В статье сделан анализ денежных переводов с помощью платежных систем, а также исследована их роль в развитии безналичной экономики.

Ключевые слова: платежные системы, денежные переводы, безналичные расчеты, платежные карточки, перевод с карты на карту.

Постановка проблеми у загальному вигляді i iї зв'язок 3 важливими науковими та практичними завданнями. Сьогодні актуальною темою у світовій фінансовій дискусії є розвиток безготівкових платежів національних економік, а саме - збільшення частки безготівкових коштів платежу, аж до повного витіснення готівки 3 обороту. Розвиток «безготівкової економіки» $є$ одним 3 пріоритетів фінансових регуляторів ряду країн, як розвинених, так $і$ країн, що розвиваються. Значна кількість компаній та бізнесасоціацій працює над створенням і розвитком необхідних для цього інструментів та механізмів. В Україні сьогодні ще недостатня швидкість розвитку в цій галузі, де ряд бар'єрів, уповільнюють витіснення 3 обігу готівки. 3 одного боку, неодноразово декларувався стратегічний рух, щодо розвитку безготівкової економіки, як на рівні державних органів, так і на рівні найбільших гравців фінансового ринку, а з іншого - швидкість зростання безготівкового обігу недостатня і повинні бути зроблені певні зусилля щодо його прискорення.

Платіжна система є невід'ємним спеціалізованим елементом практично всіх економічних операцій, що стосується передачі грошової вартості в обмін на товар, послугу або фінансовий актив в безготівковій формі. Тому дослідження ролі платіжних систем у розвитку безготівкової економіки набуває сьогодні особливого значення і $є$ актуальним та доцільним.

Аналіз останніх досліджень, у яких започатковано вирішення проблеми. Дослідження питань щодо перспектив розвитку безготівкової економіки займалися науковці та економісти практики: Furst Н, В. Дикий, В. Кравець, Р. Кравець, А. А. Олешко, А.М. Ніколаєва та ін. Проте, питання щодо особливої ролі систем переказу коштів в безготівковій економіці та їх значення для соціально- 
економічного розвитку залишаються відкритими і потребують ретельного дослідження.

Цілі статті. Метою даної статті є аналіз грошових переказів за допомогою платіжних систем та дослідження їх ролі у розвитку безготівкової економіки в державі.

Виклад основного матеріалу дослідження 3 повним обгрунтуванням отриманих наукових результатів. Сучасна економіка будь-якої держави являє собою розгалужену мережу складних взаємовідносин господарюючих суб'єктів. Основою цих взаємозв'язків є розрахунки і платежі, в процесі яких відбувається задоволення взаємних вимог і зобов'язань. Реалізація валового продукту, використання національного доходу і всі наступні процеси розподілу в економіці забезпечуються на основі грошового обороту в готівковій та безготівковій формах. Основну частину грошового обороту складає платіжний оборот, в якому гроші функціонують як засіб платежу і використовуються для погашення боргових зобов’язань, як у готівковій, так і в безготівковій формі.

Формою організації безготівкового платіжного обороту $\epsilon$ платіжна система. Платіжні системи відіграють значну роль в забезпеченні економічної діяльності: створюють умови для руху грошових коштів між учасниками економічного обороту, дають можливість ефективно використовувати фінансові ресурси, проводити державну грошово-кредитну політику. Організація платіжних систем держави безпосередньо впливає на стабільність його фінансової системи, рівень витрат грошового обігу, вартість економічних операцій, ліквідність фінансових ринків і банківської системи, тобто на ефективність функціонування економіки в цілому.

Відповідно до Закону України «Про платіжні системи та переказ коштів в Україні» під платіжною системою розуміють платіжну організацію, членів та учасників платіжної системи, а також сукупність відносин між ними, що виникають у процесі здійснення переказу грошей. Платіжна організація - це юридична особа, яка визначає правила роботи платіжної системи та виконує функції щодо забезпечення іiі діяльності [1]. Основними завданнями платіжних систем є: забезпечення стійкого грошового обігу; забезпечення суб'єктів ринку платіжними засобами та платіжними інструмен- 
тами; своєчасне здійснення усіх розрахунків і платежів та сприяння динамічному розвитку безготівкової економіки.

Згідно 3 даними міжнародних досліджень, можна виділити три типи ефектів від збільшення частки безготівкових грошей в економіці: транспарентність (прозорість): група ефектів, пов'язана 3 високим рівнем обліку грошових операцій, підвищенням збирання податків, зменшенням частки тіньової економіки, зниженням операційних витрат різного роду бізнесу і т.д., що говорить про переваги безготівкових платежів. Основним бенефіціаром в даній області виступає держава. Безготівкові платежі пройшовши авторизацію стають більш прозорими, що збільшує загальний рівень транспарентності в економіці.

Стійкість: системи 3 високою часткою безготівкових платежів більш стійкі до зміни економічної кон'юнктури, так, як у фазі рецесії безготівковий обіг сприяє додатковому джерелу ліквідності фінансової системи та зростанню пасивів комерційних банків, відкриваючи нові можливості для підвищення активів.

Зростання: збільшення частки безготівкових платежів впливає на загальне економічне зростання країни через підвищення швидкості транзакцій і збільшення їх кількості за рахунок зниження собівартості кожної транзакції.

За підсумками 2017 року на ринку систем переказу коштів, створених резидентами, лідером за сумою переказів є міжнародна платіжна система TYMЕ (1360 млн дол. США в еквіваленті), в якій працює 3500 терміналів самообслуговування, за допомогою, яких крім переказів можна оплатити послуги Інтернет, мобільний зв'язок та ЖКГ. Партнерами системи є Нова пошта та 7 банків. За допомогою системи відправити переказ можна в 12 країн, а отримати $з 8$ країн.

На другому місці з грошових переказів система Укрпошти Поштовий переказ (\$1281 млн дол. США в еквіваленті). Крім найбільшої регіональної мережі в Україні, перевагою цього сервісу $є$ можливість здійснювати перекази за кордон. Третє місце зайняла система переказів ІнтерПейСервіс (\$736 млн дол. США в еквіваленті), приймаючи оплату комунальних платежів в Запоріжжі (рис. $1)$. 
Економічні науки". - Серія "Облік і фінанси". - Випуск 15 (57). - 2018.

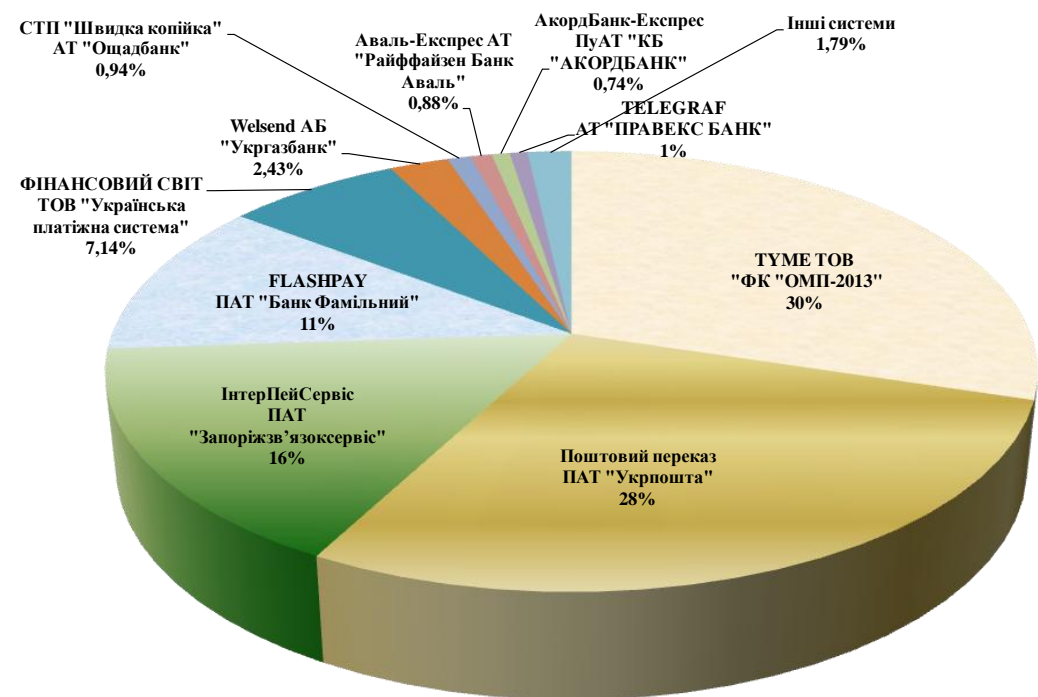

Рис. 1. Розподіл сум переказів у розрізі платіжних систем створеними резидентами, в межах України за 2017 рік, \%

За допомогою платіжних систем, створених нерезидентами у 2017 році було здійснено переказів в Україну на суму 2264,26 млн дол. США, за межі України - 282,98 млн дол. США та в межах 2,68 млн дол. США. Серед платіжних систем переказу коштів, створених нерезидентами за обсягами здійснених переказів посідає Western Union (54\% усіх транскордонних переказів в Україну та $74 \%-3$ України, рис. 2).

Україна залишається країною-реципієнтом транскордон-них переказів. Сума коштів, отриманих в Україні з використанням міжнародних систем переказу коштів, у вісім разів перевищує суму коштів, відправлених за їі межі [2].

У 2017 році всього в Україну було переказано \$2377,92 млн дол. США в еквіваленті. Найбільше було здійснено переказів 3 Роciї та США. 3 України було здійснено переказів на суму $\$ 286,04$ млн дол. США в еквіваленті. Найбільше коштів було переказано до Росії та Грузії (рис. 3). 
Економічні науки". - Серія "Облік і фінанси". - Випуск 15 (57). - 2018.
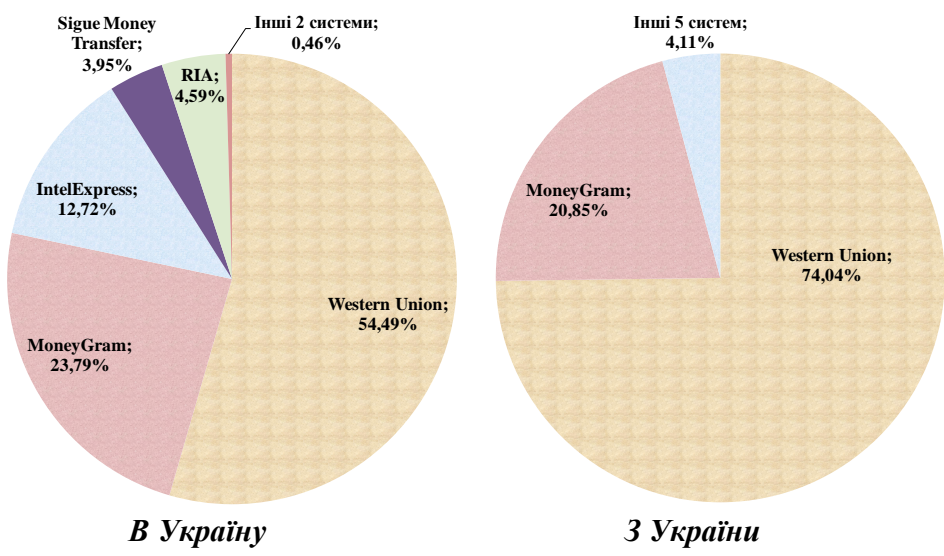

Рис. 2. Розподіл сум транскордонних переказів у розрізі платіжних систем створеними нерезидентами за 2017 рік, \%

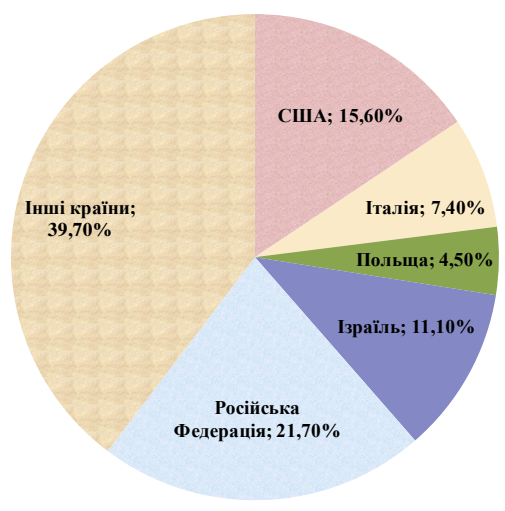

В Україну

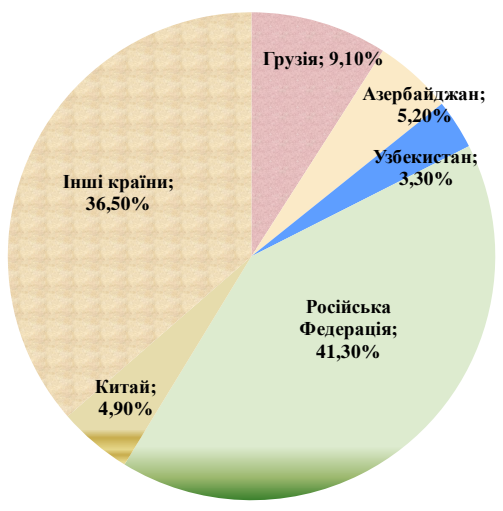

3 Украӥни

Рис. 3. Транскордонні перекази в розрізі ТОП-5 країн за 2017 рік

Потік переказів з Росії в Україну перевищує \$1,3 млрд на рік. В Росії ще перебуває близько 3 млн українців, з яких велика частка заробітчани і тільки офіційне працевлаштування дає змогу отримувати зарплату на банківську картку, що автоматично робить досту- 
пними усі способи безготівкового переказу грошей. Найбільш зручний, безпечний та швидкий це - переказ з картки на картку.

Використовуючи платіжні картки протягом першого півріччя 2017 року було здійснено 1055 млн шт. безготівкових операцій на суму 348 млрд грн. Перекази з картки на картку становили 86,8 млрд грн, (25\%). У 2018 році за шість місяців було здійснено 1423 млн шт. безготівкових операцій на суму 573 млрд грн. Перекази 3 картки на картку зросли на $6,1 \%$ і становили 177,9 млрд грн $(31,1 \%$, рис. 4).

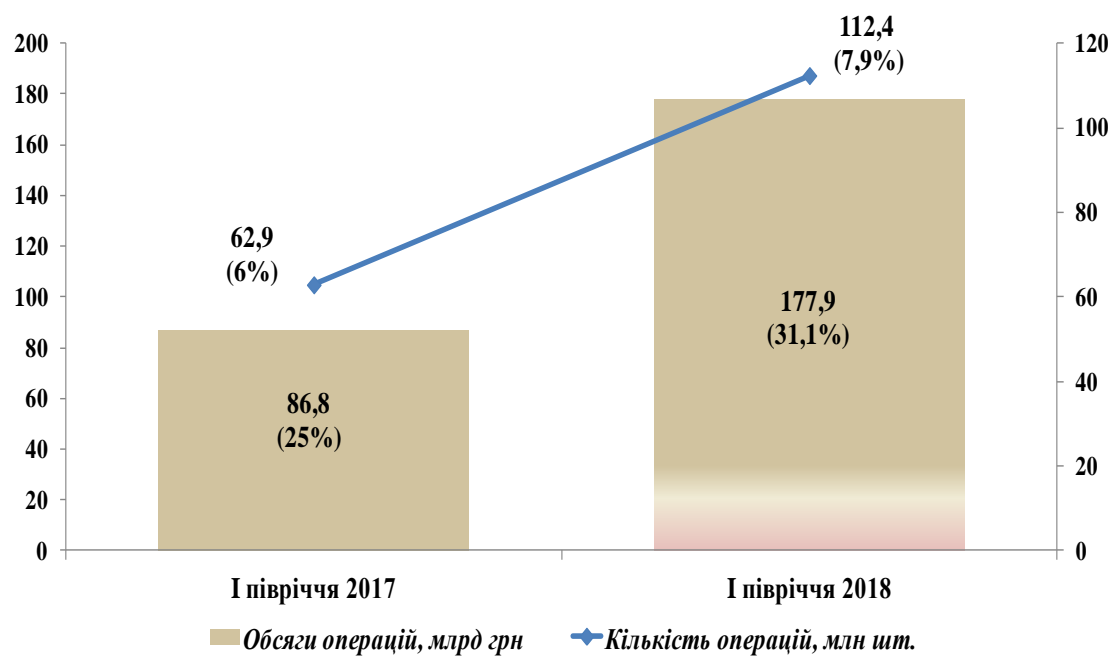

Рис. 4. Динаміка обсягів та кількості переказів з картки на картку

На українському ринку переказ коштів 3 картки на картку (онлайн-переказ p2p) знаходиться ще на стадії становлення. Даний сервіс не передбачає відвідування банку а проводиться через Інтернет або мобільний додаток, що дуже зручно і оперативно. На відміну від інших способів переказу грошей таких як готівковий, електронні гроші, p2p-переказ має ряд переваг: коштує значно дешевше; здійснюється абсолютно в будь-який час, навіть вночі; переказ можна здійснити в будь-якому місці, де є доступ до Інтернет; операція може проводитися як зі стаціонарного комп'ютера, так і 3 
мобільного телефону, достатньо знати лише номер картки одержувача; можна здійснювати онлайн-перекази грошей на картки користувачів інших банків. Р2Р-перекази набирають великої популярності і поступово витісняють операції за допомогою традиційних систем, адже це $є$ зручним і доступним сервісом при мінімальних затратах.

Висновки. Згідно наведених даних можна зробити висновки, що сучасний стан платіжних систем і безготівкових розрахунків в Україні свідчить про їх динамічний розвиток. Ринок грошових переказів у безготівковій формі також останнім часом розвивається досить активно. Активність у боротьбі за досить перспективний ринок виявляють і банки сусідніх держав. На зростання конкуренції, зниження тарифів і зростання якості послуг також дуже впливає конкуренція з боку сучасних карткових і криптографічних технологій переказу коштів. Уже сьогодні вітчизняні тарифи переказу грошей нижчі за світові тарифи, і є всі підстави вважати, що дана послуга незабаром буде ще комфортнішою й дешевшою, а більшість внутрішньобанківських систем переказів спробують набути статусу загальнонаціональних та міжнародних, стрімко розширюючи географію насамперед за рахунок співпраці 3 вітчизняними банками, а також банками колишніх союзних республік і Європи. Таким чином, розвиток платіжних систем, їх ефективна інтеграція, грають значну роль в забезпеченні стабільного розвитку безготівкової економіки.

1. Закон України «Про платіжні системи та переказ коштів в Україні» [Електронний ресурс]. - Режим доступу: http://zakon.rada.gov.ua/laws/show/ 2346-14.

2. Дані щодо діяльності в Україні систем переказу коштів, створених резидентами та нерезидентами [Електронний ресурс]. - Режим доступу: https://bank.gov.ua/control/uk/publish/article?art_id=64288362\&cat_id=105262.

3. НБУ оприлюднюватиме інформацію про розподіл обсягів та кількості безготівкових операцій з використанням платіжних карток [Електронний ресурс]. Режим доступу: https://bank.gov.ua/control/uk/publish/article?art_id=55393524 \#top.

4. Про підсумки діяльності систем переказу коштів [Електронний ресурс]. Режим доступу: https://bank.gov.ua/control/uk/publish/article?art_id $=64628178$.

5. Ніколаєва А.М. Ринок систем грошових переказів в Україні / А.М. Ніколаєва, С.О. Пиріг, Л.І. Іщук // Економічні науки. - Серія «Облік і фінанси»: зб. наук. праць. - Вип. 13 (49). - Ч. 2. - Луцьк: РВВ Луцького НТУ, 2016. - С.188-198. 